\title{
Anthropomorphic Climate Change? Some American Undergraduates Think It Is All Political
}

\author{
David A. Cline
}

\begin{abstract}
This is the second paper to be generated from work first presented in Rome in 2016. During 2015 and 2016 a sample of American undergraduate students were given an anonymous survey to ascertain their knowledge about global warming and climate change. The survey asked the students to indicate the degree of truth they perceived about a climate change statement on a 1-5 scale. A score of 1 meant the statement was true while a score of 5 indicated the statement was false. As a follow up assignment the students were asked to write an anonymous paragraph to further explain their understanding. Surprisingly, the scores on the survey grouped around 3.0 - not sure. It emerged from the data that the sample of undergraduates didn't believe humans were contributing.

The major surprise for the researcher was the degree to which the writing showed how this sample of college students believed anthropomorphic global warming is a hoax, a plot, or a takeover move of the United Nations. The responses are littered to references to "liberals". Examples and analysis of student writing is provided. Some parts of the previous article are repeated for framing and clarification.
\end{abstract}

Index Terms-Climate change, anthropomorphic, denial, undergraduate, education.

\section{INTRODUCTION}

"This mindless tolerance, which places observable scientific facts, subject to proof, on the same level as unprovable supernatural fantasy, has played a major role in the resurgence of both anti-intellectualism and anti-rationalism." - Susan Jacoby, The Age Of American Unreason [1].

For most who work in the academic or scientific sectors the factual nature of human impact on climate change is accepted as true. There are a few skeptics and contrarians who represent a healthy questioning in the scientific enterprise, but by and large there is consensus, if not agreement, that human activity, predominantly the burning of fossil fuels, is a major factor in Earth's changing climate. Thomas Kuhn said, "If these out-of date beliefs are to be called myths, then myths can be produced by the same sorts of methods and held for the same sorts of reasons that now lead to scientific knowledge" [2].

As part of an undergraduate science methods class for elementary teacher candidates a survey was given to get a glimpse of students' thinking about the topic of global warming (in general) and humanity's impact (in particular). To this end, students were given a list of statements taken from the Skeptical Science website and were asked to rate

Manuscript received April 27, 2016; revised January 11, 2017.

David A. Cline is with Saginaw Valley State University, University Center, MI 48710 USA (e-mail: dacline@svsu.edu). each statement with a score of 1 - true, 2 some truth, 3 not sure, 4 mostly false, or 5 totally false.

The students, after completing the survey, were asked to write about their knowledge of global warming. This writing was done between class periods, was anonymous, and was designed to let students present any opinion.

What the students wrote was a fascinating insight into their developing scientific and political minds.

\section{STUdENT OpINIONS}

The United States has become increasingly politically polarized over the past twenty-five years and some would say even more so during the presidency of Barack Obama. (Pew Research Data) [3]. To that end, Americans sometimes categorize each other as conservative or liberal depending on consumer choices. For some, a Mac computer and a Toyota Prius would be considered the choices of a liberal consumer while a PC and a Chevrolet Suburban would be more conservative choices. As ridiculous as this seems this division has become part of American daily life.

Needless to say, one's political views are also on display when discussing human impact on climate change. If one is convinced of the truth of anthropomorphic climate change that person is seen by more conservative Americans as a "tree-hugging liberal". On the other hand, those Americans who do not believe in humans as a cause of global warming are seen as backward, ignorant, or purchased by the fossil fuel industry.

It also seems that Americans who do not think global warming is correct will speak of elaborate hoaxes or even plots from the United Nations to tax the middle classes into poverty.

\section{A. It's a Hoax}

One student wrote: "And the beat goes on and on; no real science, just emotions and these nut jobs just keep singing the same tune. I say that we ask all of these people who believe in this climate change hysteria, caused by mankind, to give up every luxury they have and every form of technology, from the car they drive to the A/C they use to cool their homes, and let's measure the effects. Then when the results are in we'll do the same thing?" (Note: this student is referencing the work of Ian Pilmer [4] and the American Environmental Protection Agency [5]).

Another wrote: "Global Warming is essentially a Religion created to promote Socialism. And defeating Socialism is indeed the moral challenge of our time. That said my fellow Capitalist Skeptics, tread gently, because very few alarmists are 'in' on the scam. The science, as a rule, is pathological rather than falsified. Climate Scientists simply see any 
temperature increase as human caused because they 'just know' humans are causing it. If Global Temperatures plateau, then the heat they 'just know' is there must be hiding somewhere."

These students show the belief in a hoax or a plan to inflict socialism upon the masses. As surprising as this reply is it was typical in student responses.

Another student echoes a similar sentiment. "The political class is perfectly happy to shut down the energy industry, so as to establish themselves as permanent rulers. Just as Marx targeted the Bourgeoisie, the "yuppies' of their day, so now politicians have targeted the regular working class as having had too much upward mobility and now seeks to return them to the serfdom they suffered under socialist governments in the past. Given the historical fact that fossil carbon originated from the atmosphere (but politicians tend to be Existentialists, whose contempt for history is well known), it is a specious claim at best to assert that putting but a fraction of that carbon back into the atmosphere makes for an environmental crisis, when the fact is that we are in far greater danger of running out of fossil energy before a suitable replacement is found, and governments have a truly sorry track record when it comes to technological innovation. That innovation if it is to come, will come from the private sector, the very thing that the politicians are actively trying to destroy."

\section{B. It's Evil}

Other students think it is evil to believe that the planet is warming: "The "Climate Change" hoax is evil in its purest form. If these "Alarmists" or self-proclaimed elitists get their way, the world's poorest will starve and billions will become poor and dependent upon government for survival. And that is the objective, total dependence upon a government run by the elitists. Why the dire consequences? Because these evil elitists plan to "outlaw" access or tack on huge "carbon taxes" to the world's cheap energy sources God has provided in abundance so even the poorest can have food, heat, and a roof Instead, this evil wants a governance that will tell every country how much carbon dioxide it may admit and then how they can emit it. For example, the IPCC would require drastic reductions mass farming techniques which will cause food to become scarce, prices to sky rocket, and be unaffordable or unavailable for our poorest. No matter, the poorest won't be able to heat their shelters or cook anyway. No fuel. But then, the "elitists" behind the "Climate Change" movement believe there are too many people on earth making their opulent life styles "unsustainable". So rather than give up that forth house or downsize their private jet fleet, why not get rid of a bunch of people through starvation."

\section{Working to Slow or Stop Global Warming Is a Moral Imperative}

Some students who spoke in class about efforts to make the planet a better place for their children were met with resistance from other students. This moral challenge was met with the derision of others.

"In the liberal mind if I spill my coffee it is directly related to 'global warming'. If I trip on a crack in concrete, catch a cold, a bird poops on my car, or if a restaurant screws up my order it's all directly related to 'global warming'. Only massive expansion of government funded by unprecedented taxation will solve this non-existent problem..."

"Moral challenge? Are they nuts? How can an imaginary "global warming" be a challenge? Oh wait, these are dumbocraps (Slang term for liberal American Democrats) that we are discussing. I stand corrected. They are, by definition, mentally challenged. Without a cue card, they don't have a clue."

\section{Reason}

The entire class was not made of global warming deniers. Some students discussed the oddity that is anti-intellectualism and the anti-science movement in the United States.

One student wrote:"As long as the GOP (Grand Old Party - another name for the American Republican party) says Global Warming is a lie, the entire right political side will follow. Why can't people just think on their own? Global Warming is not a political belief; it is a scientific fact. It isn't a philosophy.

At this rate our entire society is dependent upon what Congress believes? And the GOP claim they want less government. Claim they want independence yet they don't show any independent thinking.

Another student injected levity."Nope...no problem here. I don't feel a thing!" (said the toad sitting in the water filled pot that itself sits on the stove with the burner cranked up).

And one student was even taking the role as teacher.

"You must not confuse weather, which is local, with climate, which is worldwide and on-going. A winter does not indicate the elimination of summers and your local weather one time does not say anything about climate over the planet. Ice melts and freezes along a pattern which is changing because the climate is getting increasing amounts of energy from the sun stuck in the atmosphere, ie the greenhouse effect. The point is the overall trend, the climate pattern, is less ice, more heat. It is vital you not conflate short term patterns with long term patterns. Weather is short term; climate is long term. Things change over time and for several decades the changes have been more energetic producing wilder weather and melting more ice and raising the ocean levels. Every winter in January I get a week or so of warm weather and the snow melts back a bit. This does not mean the end of winter! The snow returns and it is winter. That's called "weather" and it is produced by changes in climate. In the long term things are getting warmer."

\section{CONCLUSION}

So, in conclusion, two students offer these gems of wisdom.

"Let's hear it what is the new Liberal solution for this grave Global problem? Oh yes raise taxes and expand the government, create are government agency to watch the ice melt and give doomsday reports to the public to keep them in panic and crying $\mathrm{OH}$ wise and wonderful Liberal government save us, take all our money and property. So as usual the Liberal socialist answer is Taxes and prosecute Deniers, yep that will save the planet."

"Wow. The Earth is warm and ice is melting. Who could have predicted that? Please let us know what the next 
Chicken Little doomsday event will come to pass so we can get ready for it."

I'm going to break with the formal style and relate a brief story that I shared in the first paper regarding my experience with the controversial (in the minds if my students) global warming issue.

When I was little my father and I encountered a black snake on a walk through the woods. I wasn't scared of the snake, but I was scared of my father's reaction. He was deathly afraid of snakes. I wasn't, but I quickly learned that I should be. So great was this fear I learned that I avoided any place a snake might live and I might even be startled by a picture of a snake.

As I grew I learned that not all snakes are deadly and most are quite beneficial. I learned to handle common snakes and not to kill them on sight. The curious part of the story is that if I am working outside and encounter a snake my initial reaction is to jump and be scared - the emotional part of my brain reacts before the thinking part takes over. Once the shock has passed the rationality commences.

The point is humans learn things easily - especially if emotion is involved. The negative to this is if we humans learn something incorrect it is difficult for the new knowledge to find purchase.

It is my guess that these students have been hearing about global warming for most of their lives and they have instilled in them the voices of family, friends, internet sites, talk radio hosts, and schooling. Some information fits their view of the world, other information doesn't fit and is to be discarded. National Geographic [6], quoting the work of Andrew Shtulman, describes it like this.

Even when we intellectually accept these precepts of science, we subconsciously cling to our intuitions-what researchers call our naive beliefs. A recent study by Andrew Shtulman of Occidental College showed that even students with an advanced science education had a hitch in their mental gait when asked to affirm or deny that humans are descended from sea animals or that Earth goes around the sun Both truths are counterintuitive. The students, even those who correctly marked "true," were slower to answer those questions than questions about whether humans are descended from tree-dwelling creatures (also true but easier to grasp) or whether the moon goes around the Earth (also true but intuitive). Shtulman's research indicates that as we become scientifically literate, we repress our naive beliefs but never eliminate them entirely. They lurk in our brains, chirping at us as we try to make sense of the world.

So, as liberal college professors and educators there should be a healthy dose of skepticism in our teaching and learning. We should also recognize when we are wrong. A solution can be the addition of critical thinking exercises in our curricula. Students must be thought to think for themselves and not regurgitate what they have been taught. Lots can be learned, good and not so good, by listening to students.

\section{EPILOGUE}

In August 2016 when this paper was presented in Beijing China at the ICERI international conference, a question was raised about the possibility of Donald Trump becoming president of the United States. At that time the room erupted into laughter. We were an assembled body of educators representing Europe, Asia, and North America and none of us could have predicted a Donald Trump victory. The possibility seemed ridiculous. The questions surrounding a Trump presidency revolved around the issue of science and a general lack of intellectual seriousness toward important environmental issues.

In the weeks following the Trump victory there have been numerous cabinet appointees that suggest the United States may be going backwards in climate policy, and science in general.

Emboldened by a Trump victory, a grassroots group of anti-liberal, intolerant group of angry (mostly white) voters have emerged under the banner of "alt-right". This group seems to be opposed to diversity, science, and academia while espousing support for traditional religion, family first values, as well as white male superiority.

A look at Trump's cabinet picks paints a dire picture of science, education, and environmental issues under Donald Trump [7].

The Environmental Protection Agency position to be headed by Scott Pruitt who is critical of the agency. Pruitt's actions largely mirror Trump's own rhetoric on the campaign trail, framing the EPA as an all-too-powerful agency pursuing an ideological agenda based on what he considers dubious science.

Secretary of Energy is to be Rick Perry. The former Texas governor will lead the federal agency he said he wanted to eliminate.

Secretary of Education pick Betsy DeVos is a Michigan education activist and major donor to the Republican political party, is an advocate for school choice and charter schools.

Secretary of State will be Rex Tillerson, who has spent his career at ExxonMobil, would be the first secretary of state without government or military experience if confirmed. He has a decades-long business relationship with Russian President Vladimir Putin, which has raised eyebrows among Democratic and some Republican lawmakers.

It is not just the United States who worrys as the reader can see by this article from chemistryworld.com (Published by the Royal Society of Chemistry. Great Britan)

"As President-elect Trump revealed his picks for cabinet positions and agency director posts over the past few weeks, tensions between the incoming administration and the scientific community have risen. Many researchers, science policy wonks and environmental groups have sounded the alarm in response to Trump's nominees to head the Environmental Protection Agency (EPA) as well as the Departments of State and Energy, among others.

"Earlier this month, Trump revealed that he will nominate Oklahoma attorney general Scott Pruitt - whose official website says he is 'a leading advocate against the EPA's activist agenda' - to be the next administrator of the EPA. Pruitt, who has repeatedly sued what is set to become his agency to roll back regulations like President Obama's Clean Power Plan to cut emissions from coal-fired power plants, has often publicly said scientists continue to disagree on global warming and its connection to human activity.

"The day after Trump was elected, Pruitt told a local radio 
show that there is 'enormous dispute' about whether global warming is real. 'I believe that there will be significant regulatory change on day one,' stated Pruitt, who is being criticized for having a cozy a relationship with the fossil fuel industry.

"Meanwhile, political campaign contributions data indicate that Pruitt has received more than $\$ 300,000$ $(£ 241,546)$ in donations from the fossil fuel industry since 2002. The American Coalition for Clean Coal Electricity (ACCCE) celebrated his forthcoming nomination to head the EPA. '[Attorney] general Pruitt will be a strong advocate for sensible policies that are good for our environment, as well as mindful of the need for affordable and reliable electricity,' said Paul Bailey, ACCCE's senior vice president for policy [8].

Another take on Trump's cabinet and advisors come from The Hill. The Hill is an American political journalism newspaper and website published in Washington, D.C. since 1994 [9].

“As President-elect Donald Trump fills out his Cabinet, a few things are becoming clear: He loves generals, he prizes loyalty and he especially values the loyalty of those who funded his presidential campaign.

Trump has so far chosen four major donors or fundraisers to join his Cabinet. With just over half of the jobs filled, he already has more high-end campaign donors in his Cabinet than either President Obama or President George W. Bush did when taking office.

Obama's first Cabinet had more campaign donors - at least eight - in total than Trump, but the most any of them gave Obama was $\$ 9,000$, according to Federal Election Commission records. Many of Obama's initial picks were Democratic politicians.

Presidents often reward campaign donors with foreign ambassadorships - France is an especially prized posting and donors are sometimes offered top Cabinet positions. The current Commerce secretary, Penny Pritzker, was Obama's national finance chairman in the 2008 campaign.

Trump, however, has gone further in rewarding his biggest donors.

Former Goldman Sachs partner Steven Mnuchin, the president-elect's choice for Treasury secretary, served as Trump's top fundraiser and personally contributed $\$ 430,000$ to Trump and to the Republican National Committee's joint fundraising account.

Pro wrestling magnate Linda McMahon, Trump's pick to head the Small Business Administration, gave \$6 million to Rebuilding America Now, a super PAC that backed Trump. She also gave $\$ 153,000$ to Trump's joint fundraising account and more than $\$ 400,000$ to the RNC.

Billionaire investor Wilbur Ross, Trump's choice for Commerce secretary, had a senior role on Trump's fundraising team. He gave $\$ 200,000$ to Trump's joint fundraising account and $\$ 117,000$ to the RNC.

Andy Puzder, the fast-food CEO chosen for Labor secretary, raised campaign cash for Trump and personally contributed $\$ 388,000$ to the RNC and $\$ 150,000$ to Trump's joint fundraiser. He also gave $\$ 10,000$ to Rebuilding America Now.
Another Trump Cabinet selection, Betsy DeVos, belongs to one of the top Republican donor families in the country. The Education secretary pick, however, was no booster of Trump's. She gave $\$ 50,000$ to a super PAC supporting Sen. Marco Rubio (R-Fla.), Trump's rival in the GOP primaries. She also wired the maximum amount to another of Trump's primary rivals, Wisconsin Gov. Scott Walker.

Trump is taking a political gamble by choosing major donors for such lofty posts.

One of his biggest campaign promises was to "drain the swamp." And for 18 months he campaigned, theatrically, on the most populist message seen in recent Republican politics. He thrilled his crowds by ridiculing the donor class that he said dictates much of the Washington agenda.

Trump's first campaign manager, Corey Lewandowski, says that a big part of Trump's appeal was that the billionaire self-funded his primary campaign. Despite Trump's reversal in the general election — he began soliciting campaign donations and tacitly blessed outside super PACs - many of his fervent supporters believe he is beholden to no one.

Democrats are seeking to portray the incoming president as a man more likely to fill Washington's swamp rather than drain it.

And some of Trump's staunchest allies aren't pleased with some of the Cabinet selections, particularly Puzder.

Hours before Trump had announced Puzder on Thursday, three hard-line immigration groups criticized the fast-food CEO's selection on the grounds that he would be too sympathetic to foreign workers.

“President-elect Trump's choice of Andrew Puzder to run the Department of Labor raises questions and concerns about whether he will vigorously defend the interests of American workers," Dan Stein, president of the Federation for American Immigration Reform, said in a statement [10].

In the words of Jesus Christ, "Father, forgive them, for they do not know what they are doing." [11].

It seems that the world may be in for a rocky few years in regard to science and education.

\section{REFERENCES}

[1] S. Jacoby, The Age of American Unreason, Vintage Books, 2008.

[2] K. Thomas, The Structure of Scientific Revolutions, The University of Chicago Press, pp. 24-25, 1962.

[3] Pewresearch. [Online]. Available: http://www.pewresearch.org/fact-tank/2014/06/12/7-things-to-know-a bout-polarization-in-america/

[4] P. Ian, "Iceland volcano gives warming world chance to debunk climate sceptic myths | Leo Hickman | Environment | guardian.co.uk," April 2010.

[5] US EPA, 2010.

[6] Ngm.nationalgeographic. [Online]. Available: http://ngm.nationalgeographic.com/2015/03/science-doubters/achenba ch-text

[7] Trump-cabinet. [Online]. Available: http://abcnews.go.com/Politics/trump-cabinet/story?id=43478002

[8] Chemistryworld. [Online]. Available: https://www.chemistryworld.com/news/trumps-cabinet-picks-worry-s cience-community/2500157.article

[9] The_Hill. [Online]. Available: https://en.wikipedia.org/wiki/The_Hill_(newspaper)

[10] Homenews. [Online]. Available: http://thehill.com/homenews/campaign/309576-what-trumps-cabinetpicks-reveal

[11] Holy Bible, New International Version, Luke: 23.34. 


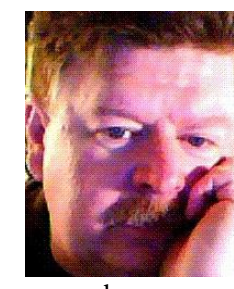

David A. Cline was born in the United States of America in July of 1956 predating Sputnik by a little more than a year. Dr. Cline holds a bachelor's degree in education and integrated science from the University of Indianapolis earned in 1978, a master's degree from Indiana University earned in 1982, and a Ph.D. from Michigan State University in Curriculum and Instruction with a cognate in ethnographic
He has been in education for 38 years as a teacher, administrator, researcher, and scholar. Currently, he teaches at Saginaw Valley State University, University Center, Michigan, USA. He presented at ICERI 15 in Seville, Spain regarding his work in bringing science inquiry methods to a school in India.

Dr. Cline is a member of the American Educational Research Association. He was also the recipient of the House Family Award for Student Impact in 2010 . 